\title{
Kelut volcano monitoring: Hazards, mitigation and changes in water chemistry prior to the 1990 eruption
}

\author{
M. BADRUDIN \\ Volcanological Survey of Indonesia (VSI), Jalan Diponegoro, Nomor 57, Bandung 40122, Indonesia
}

(Received October 19, 1992; Accepted April 8, 1994)

\begin{abstract}
Kelut volcano has a notorious history of hazardous eruptions, five this century, the last in 1990. The hazards, generally lahar-related, are generated from the crater lake at its summit. Geophysical and geochemical monitoring of the volcano and lake on a continuous basis is ensured by the VSI. The results of monitoring of geochemical parameters including temperature, $\mathrm{pH}$ and the concentrations of sulphate, boron, magnesium, chloride and $\mathrm{Mg} / \mathrm{Cl}$ ratio of the crater lake showed a significant increase about 4 months prior to the 1990 eruption, reflecting an increase in activity of the volcano.
\end{abstract}

\section{INTRODUCTION}

Kelut is a very dangerous andesitic volcano, and its eruptions have always caused victims and destroyed arable land. The main source of the disasters is the crater lake at the summit. At the time of eruption, water mixed with loose material on the slope of the volcano forms lahars or mud flows carrying large blocks of rocks which destroy the fields and villages in the plains. Since the degree of danger is a function of the volume of water contained in the crater, a system of tunnels was constructed through the crater wall to drain the lake after the 1919 eruption which forced an estimated volume of water $\left(40 \times 10^{6} \mathrm{~m}^{3}\right)$ out of the lake. After this effort, the volume of the lake water was kept at much lower levels and the danger of lahar was reduced.

To further mitigate the lahar disasters, it is essential to monitor the crater lake continuously from various points of view. With the crater lake covering the most active area, changes on the chemistry of lake water are expected to directly. reflect variations in the activity of the volcano. Chemistry of the lake water also shows the interactions between volcanic materials and the acidic water. In the present paper, the variation with time in the chemical composition of the Kelut crater lake water prior to the 1990 eruption is described.

\section{Kelut Volcano}

Kelut volcano, a strato-volcano with a crater lake at the summit, and located about $25 \mathrm{~km}$ north of Blitar in East Java (Fig. 1), rises regularly from the plain of Kediri in the west and from the valley of the river Brantas in the south. To the east and north are the volcanoes Kawi, Laksono and Anjasmoro. The alignment of the craters at the summit shows that the volcanic activity has shifted from east to west. Moreover old lava plugs as Sumbing, Gajah Mungkur and the peak forming parts of the present crater rim, gave the top a very irregular shape. The crater lake has a surface area of $0.42 \mathrm{~km}^{2}$ and a depth of $20 \mathrm{~m}$ (Fig. 2). The summit and rim are subjected to intensive erosion due to ejected water. Eruptions of Kelut volcano are characteristically short in duration, usually lasting only a few hours, but very frequent. The eruptive history which dates back to the 11 th Century is summarized in Table 1.

\section{Primary and secondary dangers}

The primary dangers of Kelut volcano are 


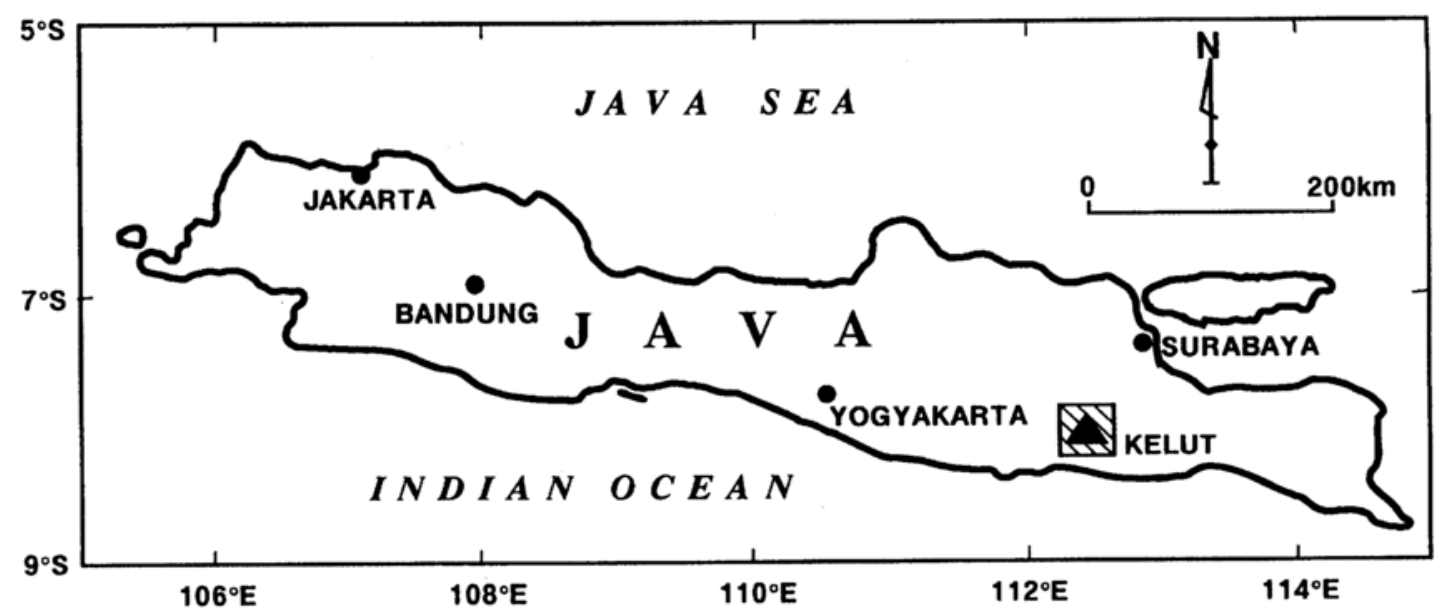

Fig. 1. Map showing the location of Kelut volcano in East Java, Indonesia.

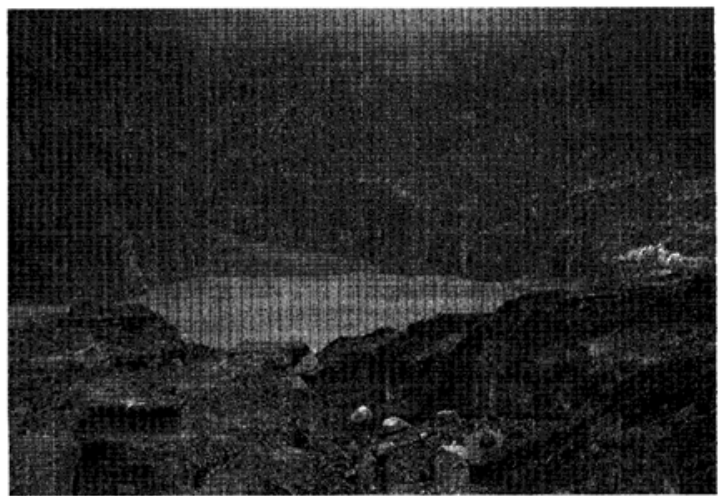

Fig. 2. Photo of Kelut crater lake in October 1992.

eruption lahars (also called primary lahars), nueé ardente, and pyroclastic falls.

The lahars flow down the river valleys to the foot of the volcano and the plains below. Lahars of this kind are generally hot. From the past experiences, we may conclude that the maximum distance of primary lahar is dependent on the amount of water in the lake. Table 1 shows a history of the volcanic hazards at Kelut volcano. During the eruptions, the primary lahars usually flowed down in all directions, but mainly to Badak river. In the 1919 eruption, the volume of the crater lake water was $40 \times 10^{6} \mathrm{~m}^{3}$. The maximum distance of the lahar was $37.5 \mathrm{~km}$, killing 5110 people with devastation of 13,500 ha land. In the 1951 eruption, the crater lake contained $1.8 \times 10^{6}$ $\mathrm{m}^{3}$ water. The lahars covered a maximum distance of $6.5 \mathrm{~km}$, destroyed 7000 ha arable land and killed 7 people. At the time of the 1966 eruption, the volume of water in the lake increased to 21.6 $\times 10^{6} \mathrm{~m}^{3}$, the maximum lahar distance was $31 \mathrm{~km}$, destroying 12,000 ha land and killing 210 inhabitants (Hamidi, 1989).

The nueé ardente travels down the slope with tremendous speed. The maximum recorded distance is approximately $8 \mathrm{~km}$ from the crater. Pyroclastic falls affect an area with a radius of about 5-7 km with volcanic bombs, lapilli, sand and ash.

Secondary dangers are rain lahars. The rain lahars occur both during the eruption and also several months or years after the eruption. Rain lahars may either be hot or cold, depending upon the time after deposition of the volcanic material.

\section{Volcanic hazard map}

Based on the past experience and the recent observations, a volcanic hazard map (Fig. 3) has been proposed by Hamidi (1989). Three zones are distinguished according to the impending hazards. They are:

1. The Forbidden Zone in which the area may be extensively affected by nueés ardente, pyroclastic falls and lahars at the time eruption. The 

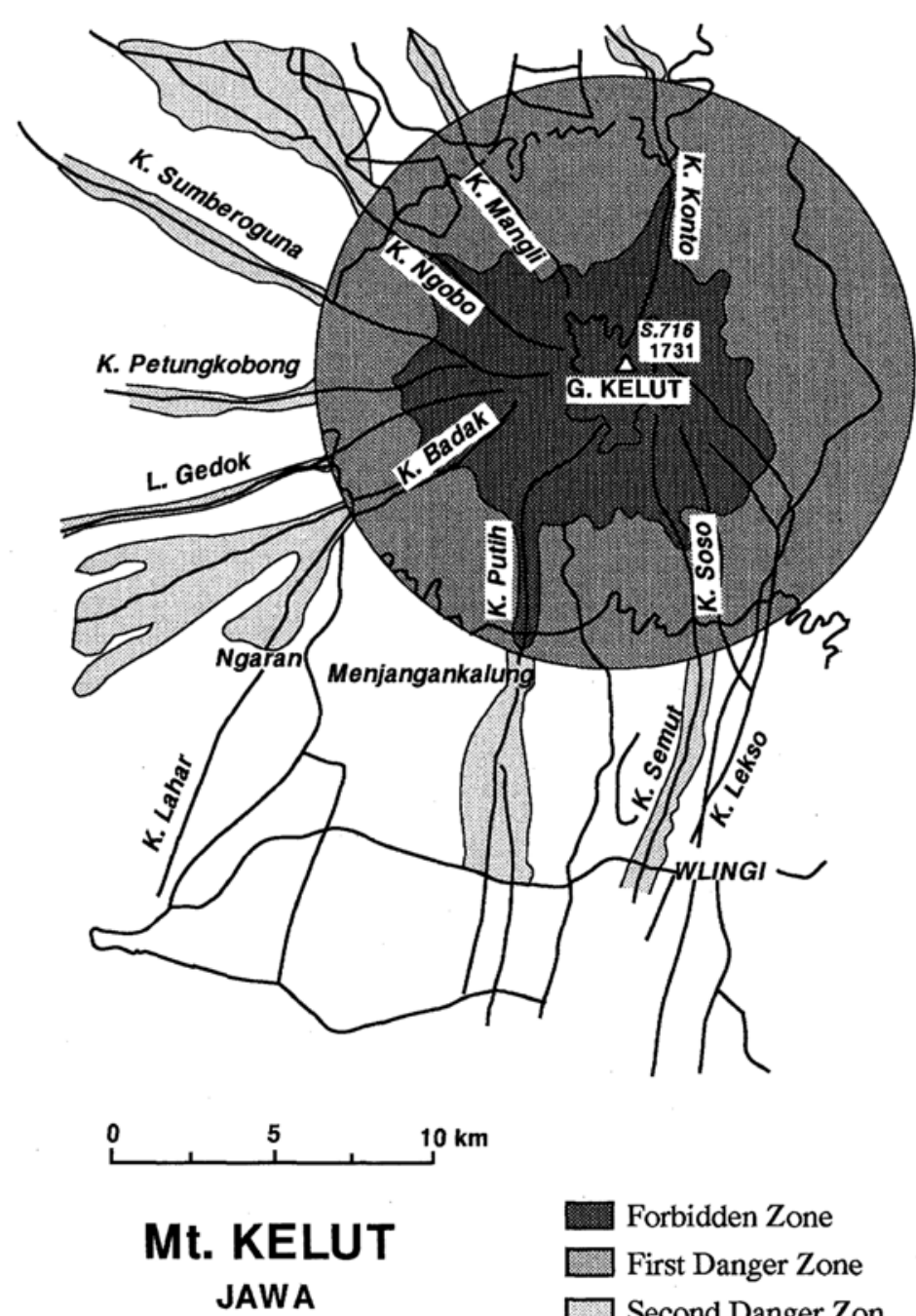

Forbidden Zone

First Danger Zone

Second Danger Zon

Fig. 3. Volcanic hazard map of Mt. Kelut (adopted from Hamidi, 1989).

radius of this zone is about $5 \mathrm{~km}$. Along the rivers it may extend to a maximum of $10 \mathrm{~km}$ from the crater. People are not allowed to live in this zone.

2. The First Danger Zone in which the area may not be affected by nueés ardente, but may be affected by volcanic bombs or by dense pyroclastic falls. The radius of this zone is $7 \mathrm{~km}$. About 6,000 people live in this zone.

3. The Second Danger Zone in which the area may be affected by rain lahars. The zone comprises of areas situated in or close to valleys radi- ating from the summit. About 80,000 people live in this zone.

\section{0 eruption}

A phreatic eruption of Kelut volcano occurred on February 10, 1990 at 11.41 a.m. followed by a magmatic eruption at 0.35 p.m. The height of eruption plume reached about $10 \mathrm{~km}$ above the summit. The eruption "nueé ardente" spread in all directions, but especially to the southwest. Water was ejected from the crater lake during the early stage of the eruption and flooded as hot water and 
Table 1. History of volcanic hazards at Kelut volcano during the last 400 years

\begin{tabular}{|c|c|c|c|c|c|c|}
\hline $\begin{array}{l}\text { Year of } \\
\text { eruption }\end{array}$ & $\begin{array}{c}\text { Volume of } \\
\text { ejecta }\left(\mathrm{km}^{3}\right)\end{array}$ & $\begin{array}{l}\text { Volume of lake } \\
\text { water }\left(10^{6} \mathrm{~m}^{3}\right)\end{array}$ & Type of hazards* & $\begin{array}{c}\text { Max. lahar } \\
\text { distance }(\mathrm{km})\end{array}$ & $\begin{array}{l}\text { Land destroyed } \\
\text { (ha) }\end{array}$ & $\begin{array}{c}\text { Number of } \\
\text { casualties }\end{array}$ \\
\hline 1586 & \multicolumn{2}{|c|}{$\begin{array}{c}\text { No information } \\
\text { idem }\end{array}$} & lh, rlh, pf, na & & Thousands & $10,000 ?$ \\
\hline 1641 & & lh, rlh, pf, na & & No information & \\
\hline 1716 & \multicolumn{2}{|c|}{ idem } & lh, rlh, pf, na & & idem & \\
\hline 1752 & \multicolumn{2}{|c|}{ idem } & lh, rlh, pf, na & & idem & \\
\hline 1771 & \multicolumn{2}{|c|}{ idem } & lh, rlh, pf, na & & idem & \\
\hline 1776 & \multicolumn{2}{|c|}{ idem } & $\mathrm{lh}, \mathrm{rlh}, \mathrm{pf}, \mathrm{na}$ & & idem & \\
\hline 1785 & \multicolumn{2}{|c|}{ idem } & lh, rlh, pf, na & & idem & \\
\hline 1811 & \multicolumn{2}{|c|}{ idem } & lh, rlh, pf, na & & idem & \\
\hline 1826 & \multicolumn{2}{|c|}{ idem } & lh, rlh, pf, na & & idem & \\
\hline 1836 & \multicolumn{2}{|c|}{ idem } & lh, rlh, pf, na & & idem & \\
\hline 1848 & \multicolumn{2}{|c|}{ idem } & lh, rlh, pf, na & & idem & \\
\hline 1851 & \multicolumn{2}{|c|}{ idem } & lh, rlh, pf, na & & idem & \\
\hline 1864 & \multicolumn{2}{|c|}{ idem } & lh, rlh, pf, na & & idem & \\
\hline 1901 & 0.002 & & lh, rlh, pf, na & & idem & \\
\hline 1919 & 0.19 & 40 & lh, rlh, pf, na & 37.5 & 13,500 & 5,110 \\
\hline 1951 & 0.02 & 1.8 & & 6.5 & 7,000 & 7 \\
\hline 1966 & 0.09 & 21.6 & & 31 & 12,000 & 210 \\
\hline 1990 & 0.012 & 2.4 & & 7 & 7,500 & 0 \\
\hline
\end{tabular}

*lh = lahar, $r l h=$ rain lahar,$p f=$ pyroclastic flow, na = nueé ardente.

Before 1586, the following eruptions are known to have taken place in; 1000, 1311, 1376, 1385, 1395, 1411, 1451, 1462, 1481 , and 1548 .

mudflows descending the volcano's flanks. From 1.00 p.m. until 5.00 p.m. of the same day, pyroclastic falls (volcanic bombs, lapili, sand and ash) reached Kelut Volcano Observatory at Margomulyo village, $8 \mathrm{~km}$ to the west of the crater. About $24 \times 10^{6} \mathrm{~m}^{3}$ of volcanic materials, consisting of "nueés ardente" and pyroclastic deposits buried the river valleys and the flanks of the volcano. These materials have a potential to become secondary lahars in the rainy season.

\section{RESUlTS AND DisCuSSION}

\section{Water-level reduction in the crater lake}

To prevent the ejection of such an enormous quantity of water and the consequent forming of disastrous mud streams, the water was drained by a system of six tunnels (tunnels I to VI) as shown in Fig. 4. Before the 1919 eruption, the volume of water in the lake was $40 \times 10^{6} \mathrm{~m}^{3}$, but had been reduced to $1.8 \times 10^{6} \mathrm{~m}^{3}$ before the 1951 eruption. Following the 1951 eruption, the crater was deepened and the volume of water in the lake before the 1966 eruption was $21.6 \times 10^{6} \mathrm{~m}^{3}$. After the
1966 eruption, tunnel VII was constructed. Since 1967 when it was completed, the volume of lake water was $2.4 \times 10^{6} \mathrm{~m}^{3}$ until the 1990 eruption.

After each eruption, VSI was able to map the crater because there was no water in it.

\section{Visual observation}

As part of the monitoring program, the Kelut Volcano Observatory has to note the changes which occur en route to and within the crater. Things to be noted are the color of the water, spreading of gas bubbles and solfataras, steam emitted above the crater lake surface, environment inside the crater lake and animal behaviour in the upper region of the volcano.

Kelut is considered to be normally active when the color of the crater lake water is dark green, gas bubbles and solfataras are not present, the steam thinly disperses, plant leaves are green and animals behave normally. Days before 1966 eruption, animals migrated to safer grounds downslope and in fact an unlucky python was captured one day before the eruption (Pardyanto, 1989). 


\section{Temperature measurement}

In 1976, in cooperation with the Department of Physics, Gajah Mada University, a tele-thermometer system to measure temperature was established at Kelut crater lake. It consisted of 3 sub-systems, namely transmitter, repeater, and receiver. The sensor was submerged in the lake water, the repeater was at a spot on the crater rim and the recorder was stationed at the volcano observatory. The system was powered by a $12 \mathrm{~V}$ battery recharged by a solar panel located at the observatory. The repeater was powered by a wind mill. The wind mill unfortunately could not withstand the strong winds and was then replaced by solar panels. There were some difficulties in obtaining spare parts for the tele-thermometer system during 1980. Data obtained were water temperature, $\mathrm{pH}$, and the water level (Mugiyono et al., 1979).

In June 1986 a new tele-thermometer was installed at the crater lake. This was donated by USGS/USAID, and has a similar sub-system to the former one; however the latter was more upto-date for it recorded electric conductivity in ad-

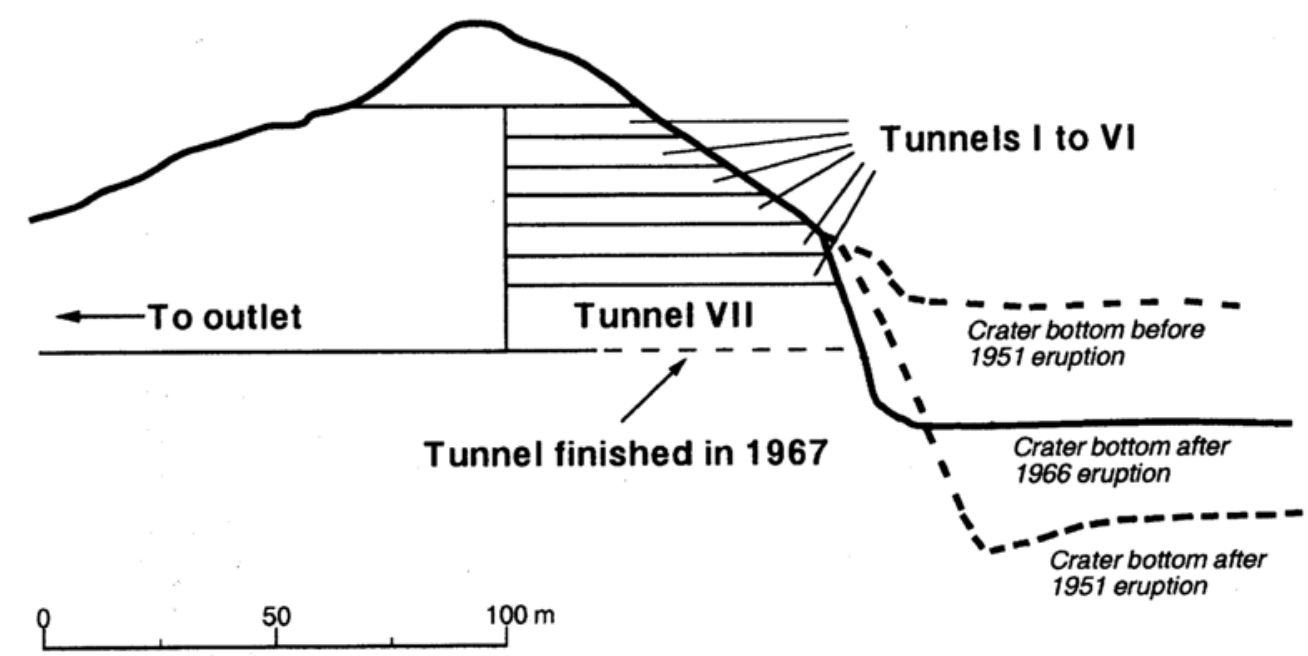

Fig. 4. The tunnel system for draining the crater lake water at Mt. Kelut.

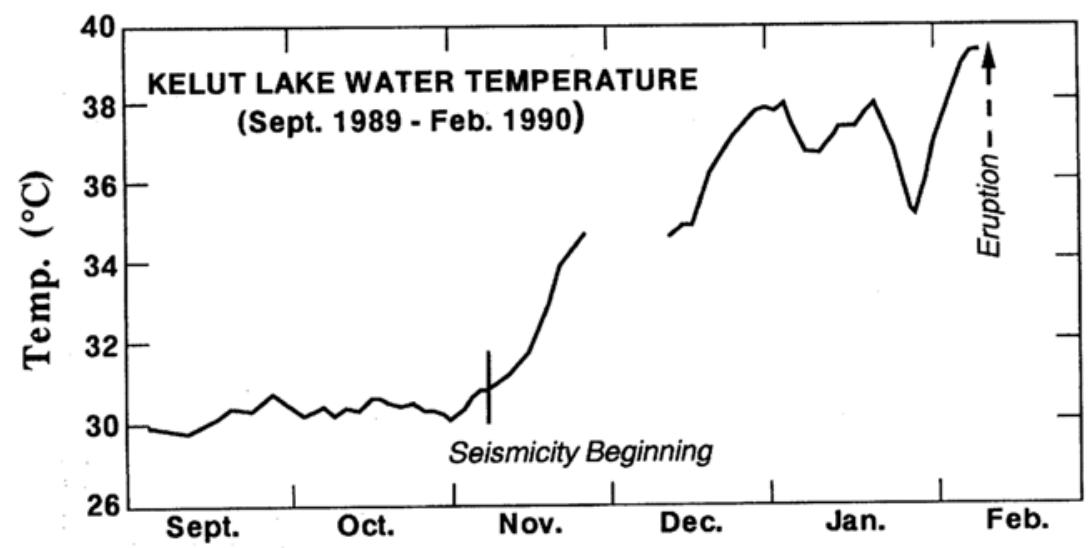

Fig. 5. Continuous temperature records of the Kelut crater lake from September 1989-February 1990 (Surono, 1992). 
dition. In a quiet stage before the 1990 eruption, the surface temperature of the Kelut crater lake water was about $31^{\circ} \mathrm{C}$. In $1988-1989$, a feasibility study was carried out in Indonesia by the Laboratory of Geophysical Instrumentation, University of Savoie, France, in order to demonstrated the capacity of the ARGOS system to transmit reliably volcanological data over long distances using satellite-relayed data transmission. The ARGOS system, comprising two NOAA spacecraft in simultaneous polar orbits, is already operational at Kelut volcano. Figure 5 shows the ARGOS temperature record of the Kelut crater lake from September 1989 until February 1990.

\section{Geochemical investigation}

The chemical composition of Kelut crater lake water is subject to considerable variations. With the crater lake covering the most active area, any change on the lake can be expected to directly reflect variations in the activity of the volcano. Chemical investigations of the water of Kelut crater lake may provide valuable information on the processes and mechanisms of volcanic activity of the volcano (Badrudin, 1989). The investigations also studied the interactions between volcanic material and acidic water. The chemical constituents of the lake water before the 1990 eruption which were important in influencing the observed variation can be considered through three principal processes:

1. Influx of acid volcanic gases, derived from sub-aqueous fumarolic activity during the eruption. Injection of volcanic gases is likely to be responsible for observed increases in $\mathrm{Cl}$ and $\mathrm{SO}_{4}$ and decrease in $\mathrm{pH}$ of lake water.

2. Leaching of new lava during mechanical and chemical disintegration of hot magmatic material on contact with lake water as well as during convective flow of lake water through fissures and fractures in the lava mass. This process is considered important and leads to an increase in the concentrations of easily leachable components $\mathrm{Si}$, $\mathrm{Na}, \mathrm{K}, \mathrm{Mg}, \mathrm{Ca}$ in the lake water.

3. Re-precipitation of dissolved material from saturated lake water, contributing to formation of ferric oxide in a syngenetic sedimentary layer.

The chemical input in the first place probably includes $\mathrm{H}_{2} \mathrm{O}, \mathrm{CO}_{2}, \mathrm{HCl}, \mathrm{HF}, \mathrm{HBr}, \mathrm{H}_{2} \mathrm{~S}, \mathrm{SO}_{2}$, $\mathrm{NH}_{3}, \mathrm{H}_{3} \mathrm{BO}_{3}, \mathrm{H}_{2}, \mathrm{~N}_{2}$, and $\mathrm{CH}_{4}$. Fumarolic steam can be expected to contribute to the heat required in maintaining the observed elevated lake temperatures. $\mathrm{CO}_{2}, \mathrm{H}_{2}, \mathrm{CH}_{4}$, and $\mathrm{N}_{2}$ pass through the acidic lake water and escape to the atmosphere without influencing the water chemistry (Sigurdsson, 1977). The basic processes influencing the lake chemistry are thought to be absorption of acid gases derived from fumarolic activity, associated with the increase of volcanic activity before eruption, and leaching of disintegrating hot

Table 2. Chemical composition of Kelut crater lake water

\begin{tabular}{lccccccc}
\hline Element & 8 June 87 & 11 July 88 & 6 Oct. 89 & 4 Nov. 89 & 3 Dec. 89 & 2 Jan. 90 & 15 Jan. 90 \\
\hline $\mathrm{SiO}_{2}$ & 160 & 176 & 171 & 172 & 180 & 191 & 191 \\
$\mathrm{Cl}$ & 173 & 175 & 171 & 196 & 178 & 210 & 224 \\
$\mathrm{SO}_{4}$ & 362 & 331 & 359 & 396 & 389 & 372 & 404 \\
$\mathrm{Fe}$ & 0.4 & 0.5 & 0.5 & 0.5 & 0.6 & 0.6 & 0.5 \\
$\mathrm{Mn}$ & 1.9 & 2.4 & 2.2 & 2.3 & 2.1 & 2.5 & 2.2 \\
$\mathrm{Ca}$ & 42.7 & 39.7 & 45.3 & 45.3 & 50.0 & 51.4 & 51.7 \\
$\mathrm{Mg}$ & 21.5 & 22.2 & 21.0 & 38.5 & 31.8 & 41.3 & 51.2 \\
$\mathrm{Na}$ & 150 & 142 & 153 & 154 & 157 & 154 & 162 \\
$\mathrm{~K}$ & 23.2 & 19.7 & 21.2 & 21.1 & 22.6 & 21.0 & 24.9 \\
$\mathrm{~B}$ & 1.1 & 1.1 & 1.1 & 2.1 & 1.9 & 2.2 & 3.1 \\
$\mathrm{NH}_{3}$ & 2.9 & 2.4 & 3.3 & 3.4 & 3.1 & 3.4 & 3.6 \\
\hline
\end{tabular}

Concentrations are expressed in ppm.

The samples represent surface waters collected onshore. 
lava in contact with water of the crater lake.

Change in magnesium, chloride, sulphate and boron concentrations and $\mathrm{pH}$ are most useful indicators to study the volcanic activity. Chloride, boron and sulphate (from $\mathrm{HCl}, \mathrm{H}_{3} \mathrm{BO}_{3}$ and $\mathrm{SO}_{2}$ ) concentrations vary in response to changes in fumarolic activity, arising from the degassing of magma. Rises in magnesium concentration are due to interaction of lake water with freshly injected, hot andesitic material (Giggenbach, 1974). Whereas $\mathrm{pH}$, decreases as degassing increases the acidity of the lake water; and increases when the water reacts with volcanic material.

Once the samples had arrived at the laboratory, part of the clear solution, later used for analysis by atomic absorption spectrophotometry, was diluted with distilled water to prevent precipitation of silica, gypsum or alunite from the solutions. Silica and major metallic elements such as $\mathrm{Na}, \mathrm{K}, \mathrm{Mg}, \mathrm{Ca}, \mathrm{Mn}$ and $\mathrm{Fe}$ were determined by atomic absorption spectrophotometry. Chlorine was titrated with $\mathrm{AgNO}_{3}$ potentiometrically or determined by a specific ion electrode. Sulphate was determined spectrophotometrically by the barium chromate method or gravimetrically as $\mathrm{BaSO}_{4}$. The chemical composition of Kelut crater lake water before the 1990 eruption is listed in Table 2.

The $\mathrm{pH}$ values decreased from 5.25 in October 1989 to 3.8 in February 1990 (before eruption), whereas boron concentration increased from 1.1 ppm to $3.1 \mathrm{ppm}$ (Fig. 6). Chloride concentration increased from $171 \mathrm{ppm}$ (October 1989) to 196 ppm (November 1989) and then increased again to $224 \mathrm{ppm}$ in January 1990 . Sulphate concentration also increased from $358 \mathrm{ppm}$ in October 1989 to $404 \mathrm{ppm}$ in January 1990 (Fig. 7). Other elements such as sodium, potassium, silicon and calcium increased in January 1990, about a month before eruption. These elements are thought to
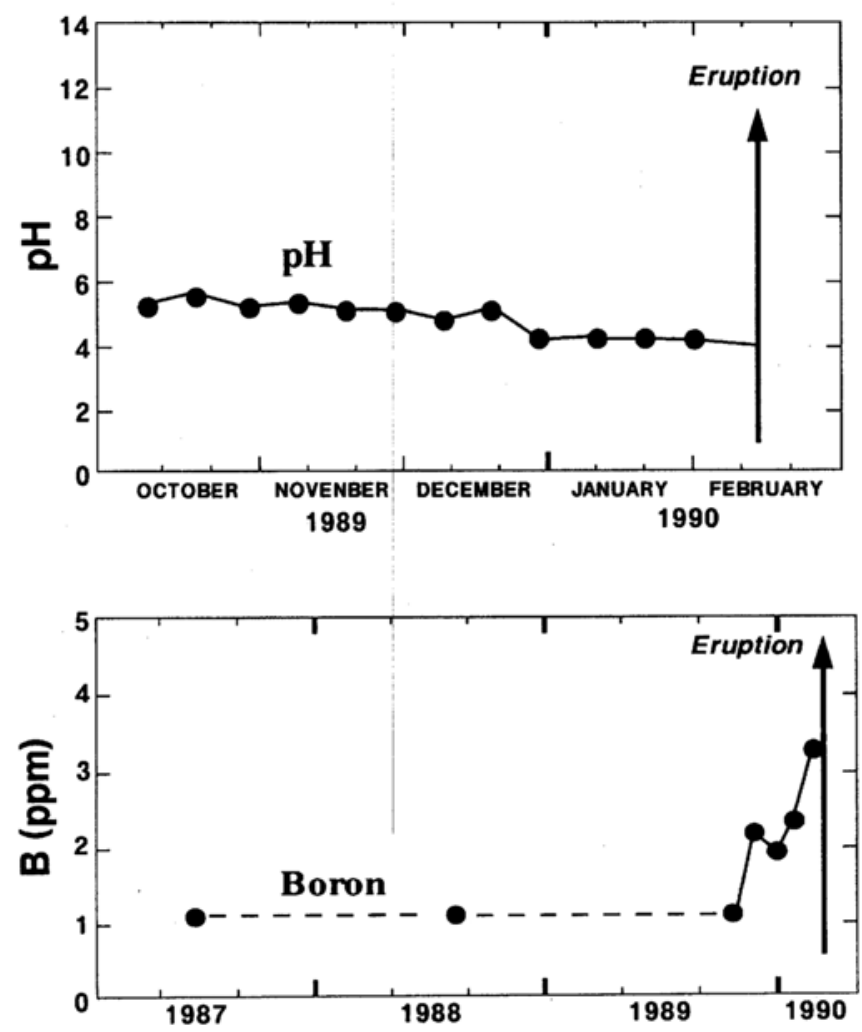

Fig. 6. Variation with time in $\mathrm{pH}$ and boron concentration of Kelut crater lake. 


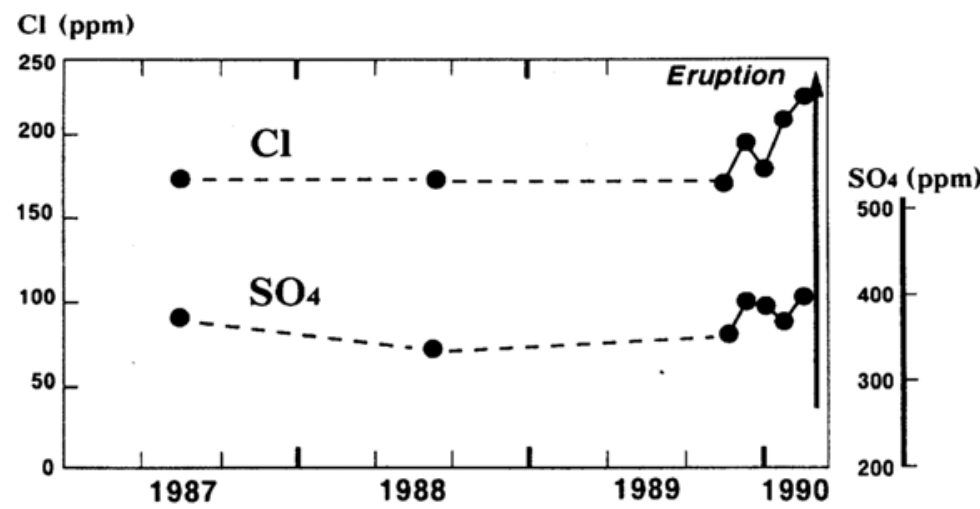

Fig. 7. Variation with time in $\mathrm{Cl}$ and $\mathrm{SO}_{4}$ concentrations of Kelut crater lake water.

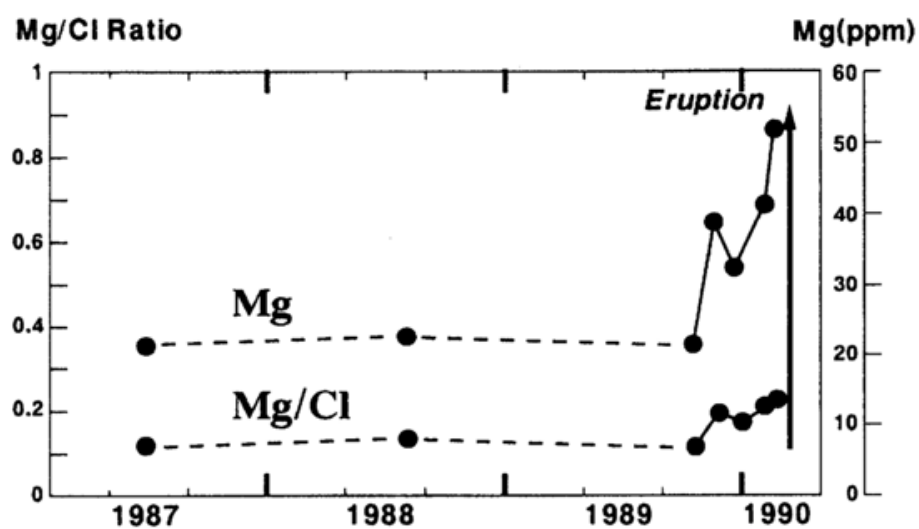

Fig. 8. Variation with time in $\mathrm{Mg}$ concentration and $\mathrm{Mg} / \mathrm{Cl}$-ratio of Kelut crater lake water.

have been leached from the lava.

$\mathrm{The} \mathrm{Mg} / \mathrm{Cl}$ ratio in the lake water reveals which of the two processes, degassing or leaching of disintegrating magma, had a predominant effect on the lake chemistry. The $\mathrm{Mg} / \mathrm{Cl}$ ratio of the lake water reflects the greater increase in $\mathrm{Mg}$ than $\mathrm{Cl}$, during the active period before 1990 eruption. The $\mathrm{Mg}$ concentration and $\mathrm{Mg} / \mathrm{Cl}$ ratio show the increase, especially in the mid of January 1990 (Fig. 8 ), indicating dominance of leaching over degassing.

Based on these analyses, some chemical concentrations, namely chloride, magnesium, boron, sulphate, and $\mathrm{pH}$, were found to provide the most sensitive information in the surveillance of volcanic activity. It can be inferred that the activity of
Kelut volcano has increased since November 1989 as indicated by the increase of chloride, sulphate, boron and magnesium contents in the lake water, and the decrease of $\mathrm{pH}$.

\section{CONCLUSIONS}

1. The increase of chloride, sulphate and boron concentrations in the crater lake, as well as the increased acidity $c a .4$ months prior to the 1990 Kelut eruption may be related to the intensifying volcanic activity which led the increased injection of acid volcanic gases into the lake water.

2 . The interactions between volcanic materials and acidic water are thought to be the principal source of enrichment of easily leacheable compo- 
nents such as $\mathrm{Mg}, \mathrm{Ca}, \mathrm{Na}, \mathrm{K}, \mathrm{Si}$ in Kelut crater lake water.

3. The $\mathrm{Mg} / \mathrm{Cl}$ ratio increases during active periods indicating dominance of leaching over degassing.

Acknowledgments- I am grateful to Dr. Wimpy, Director of Volcanological Survey of Indonesia, for his permission to publish this paper, and to Drs. S. J. Freeth, M. Halbwachs and M. Kusakabe for their critical reviews.

\section{REFERENCES}

Badrudin, M. (1989) Review of Mt. Kelut crater lake geochemical investigation. Proc. Indonesia-French Volcanol. Semin., Bandung, November 24-28, 1986, p. 257.
Giggenbach, W. F. (1974) The chemistry of Crater Lake, Mt. Ruapehu (New Zealand) during and after the 1971 active period. N.Z. J. Sci. 17, 33-45.

Hamidi, S. (1989) Kelut and Lamongan hazard maps, Proc. Indonesia-French Volcanol. Semin., November 24-28, 1986, p. 244.

Mugiyono, R., Kirbani, R. and Fadely, M. (1979) A short description of the telemetric system installed at the Kelut volcano. Gajah Mada University-Volcanological Survey of Indonesia, Yogyakarta, p. 3.

Pardyanto, L. (1989) Review of Kelut volcano monitoring methods. Proc. Indonesia-French Volcanol. Semin., Bandung, November 24-28, 1986, p. 248.

Sigurdsson, H. (1977) Chemistry of the crater lake during the 1971-1972 Soufiere eruption. J. Volcanol. Geotherm. Res. 2, 165-186.

Surono (1992) Etude de phenomenes physiques observes lors d'une intrusion magmatique. Cas du Volcan Kelut (1990) et de la caldera de Long Valley. Thesis, 1990, p. 69. 